\title{
REVIEW
}

\section{Freshwater bivalves rearing: a brief overview}

\author{
Benedetto Sicuro
}

Received: 14 January 2015 / Accepted: 27 February 2015/Published online: 19 March 2015

(C) The Author(s) 2015. This article is published with open access at Springerlink.com

\begin{abstract}
Freshwater bivalves farming is principally focused on freshwater pearl production in Asia and conservation aquaculture in USA while in Europe is almost completely unknown. High larval mortality is considered the bottleneck in freshwater bivalve larval rearing and methods currently used in marine bivalve larval rearing can be transferred in freshwater mussels. It is likely that probiotics and aquatic microbiology will play a key role also in freshwater bivalves larval rearing. Alternative applications of freshwater mussel rearing should be studied in deep in the future as integrated productions, bioindication projects and utilization of freshwater mussel meal as potential source for fish feeds. The aim of this review is to give a description of potential applications for freshwater bivalve rearing and possible future perspectives.
\end{abstract}

Keywords Bivalves · Aquaculture $\cdot$ Probiotics $\cdot$ Larval nutrition · Integrated aquaculture $\cdot$ Mussel farming

\section{Introduction}

Considering their large size, freshwater farmed bivalves belong mainly to Unionidae (Bivalvia: Unionidae Rafinesque, 1820) that is the largest family of freshwater bivalves in the world. Unionids have a world-wide distribution with very high species diversity in North America, in China and South East Asia (Karatayev et al. 2007; Bogan 2008; Bogan and Roe 2008). In this moment, freshwater bivalves farming is mainly focused on freshwater pearl production in Asia and conservation aquaculture in USA, moreover in Southern India freshwater mussel are reared for human consumption (FAO 1986; Chakraborty et al. 2008). In Europe freshwater mussel farming is almost unknown and freshwater bivalves are investigated principally for the relation with the diffusion of non-native species, as zebra mussel (Dreissena polymorpha) and Chinese pond mussel (Synanodonta woodiana). The presence and diffusion of non-native species represents a serious threat for US freshwater bivalves as already stated by a letter to Nature in 1997, "Freshwater unionid clams in North America have been virtually eliminated from waters that are colonized by zebra mussels" (Nichols and Wilcox 1997). Considering their crucial role in the freshwater ecosystem and the decline of natural populations (Bogan 1993; Lydeard et al. 2004), several researches are currently carried out in conservation of freshwater mussel and larval rearing is still the main problem to be solved. The use of antibiotics, disinfection, probiotics and immunostimulants during the larval rearing has solved larval mortality in marine bivalves (Nicolas et al. 2004; Prado et al. 2010). Considering the literature in conservation aquaculture, freshwater

B. Sicuro $(\bowtie)$

Department of Veterinary Sciences, University of Torino, L.go Braccini, 2, 10095 Grugliasco, TO, Italy

e-mail: benedetto.sicuro@unito.it 
bivalve farming and bivalve artificial nutrition, the aim of this paper is to give a description of potential applications for freshwater bivalve rearing and possible future perspectives.

\section{The importance of reproduction and larval rearing in fish conservation aquaculture}

Conservation aquaculture pertains conservation and recovery of endangered aquatic species. It involves working with natural aquatic populations thus transferring the standard aquaculture techniques with the aim to recover them or improve their natural diffusion. In some areas of the world freshwater mussel conservation represents a crucial aspect of freshwater ecosystem conservation, for instance in the USA where up to $70 \%$ of all freshwater mussels are endangered species (Diana 2009). The commercial and recreational value of some fish species has enormously stimulated researches in fish and crayfish conservation aquaculture, while freshwater bivalves conservation has been investigated in very small extent. Fish conservation aquaculture is primarily focused on habitat improvement, biological cycle and natural reproduction and secondarily on population genetic status characterization, to preserve natural genetic diversity. Nowadays in freshwater ecosystems these techniques of conservation aquaculture are very well established and consolidated for fish species, as the case of European salmon (Salmo salar) (Stefansson et al. 2003; Maynard et al. 2004), native Salmonids in Italy (Sicuro et al. 2006), in Austria (Lahnsteiner et al. 2009), Danubie salmon (Нисо hисо) in Romania (Jungwirthi et al. 1989), sturgeons in Europe (Steffens et al. 1990; Bronzi et al. 1999) and in Russia (Secor et al. 2000; Chebanov and Billard 2001). Conservation aquaculture embraces extensive aquaculture techniques and particular attention is addressed for reproduction and larval growth that are most critical phases in the aquatic animal population management (Maynard et al. 2004; Olson et al. 2004). For these reasons, in several countries fish hatcheries have been developed as first step of an effective conservation strategy (Hallermann 2004; Paragamian and Beamesderfer 2004). On this matter it is interesting the case of Washington State (USA) where salmon hatcheries compensate the natural decline of natural population producing 100 million juvenile salmons per year (Blankenship and Daniels 2004). In Idaho, Oregon and Washington the Endangered Species Act, that is program specifically drawn for wild Salmonid conservation, chiefly focuses on hatchery managing (Olson et al. 2004). In Russia, fish hatcheries are considered the principal mean of rebuilding natural population of Caspian sea sturgeons (Secor et al. 2000).

\section{The status of freshwater bivalves rearing}

In the Asia triangle shell mussel (Hyriopsis cumingii) is the most reared mussel species in China (Xu et al. 2011), while in much less extent crown mussel (Cristaria plicata) and the swan mussels (Anodonta sp.) are reared for pearl culture. Freshwater pearl production is also an activity well developed in Bangladesh (FAO 1986), where the species used is a local edible bivalve, the Indian freshwater mussel (Lamellidens marginalis). Indian freshwater mussel is traditional food for the rural human population in the Indian subcontinent and it is an ingredient of artificial feed for fish and poultry (Chakraborty et al. 2008). In North America the techniques of conservation aquaculture for freshwater fish species have been effectively transferred in bivalve conservation strategies (Neves 1999b; Henley et al. 2001; Bogan 2008; Bogan and Roe 2008). North American native bivalves are in decline and seriously threatened by the presence of non-native invasive species, Asian clam (Corbicula fluminea) and zebra mussel (Williams et al. 1993; Lydeard et al. 2004; Parker et al. 1998; Karatayev et al. 2007; Neves 2004; Lydeard et al. 2004). Some attempt of pearl production has been also carried out (Neves 1999a; Hua and Neves 2007). European freshwater mussels (Fig. 1) are threatened by the presence of non-native ones, principally zebra mussel and secondarily Chinese pond mussel (Cappelletti et al. 2009). In Europe, research for conservation of freshwater bivalves is focused on the recovering of freshwater pearl mussel (Margaritifera margaritifera) in Portugal (Reiss 2003), Great Britain (Young and Williams 1983), Germany (Buddensienk 1995), Scotland (Hastie 2006) and Sweden (Englund et al. 2008). 
Fig. 1 Italian unionids potential candidates for freshwater mussel farming. Native species: a Anodonta cygnea, b Unio mancus; exotic species: c China pond mussel (Sinanodonta woodiana)

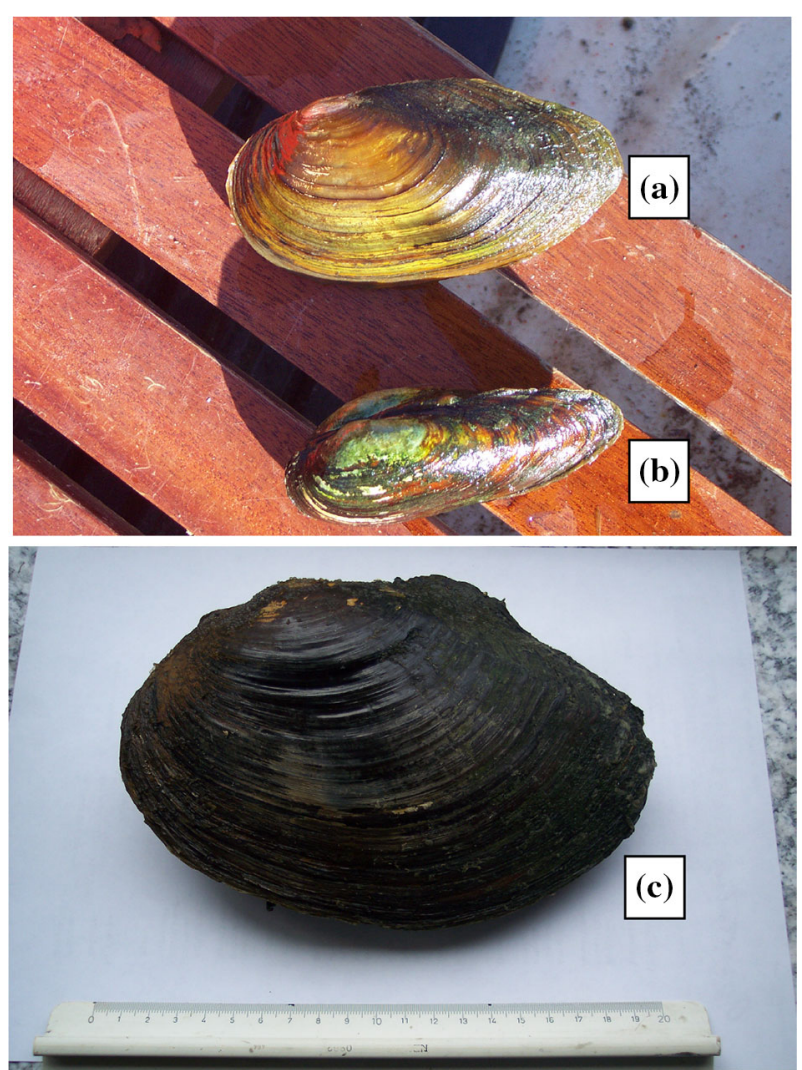

\section{Bivalve nutrition in artificial conditions}

In natural environment, freshwater bivalves diet is composed of phytoplankton, fine organic detritus and bacteria (Frischer et al. 2000). As regard as larval artificial nutrition, interesting results have been obtained using cultured microalgae as: Neochloris oleoabundans, Nannochloropsis oculata, Phaeodactylum tricornutum, and Bracteacoccus grandis (Gatenby et al. 1994; Jones et al. 2005; Wacker et al. 2002), moreover, artificial algae concentrates have been used with partial success (Nichols and Garling 2002). It is clear that the microbial water composition and sediment composition play a key role in larval nutrition as demonstrated by the success obtained especially in these recover projects that minimized the distance where mussels are moved (Raikow and Hamilton 2001).

High larval mortality is still considered the bottleneck in freshwater bivalves larval rearing (Nichols and Garling 2002; Jones et al. 2005) and possible solutions could be transferred from marine bivalve farming (Marshall et al. 2010). Efficient methods are currently used in marine bivalve larval rearing as: water disinfection, antibiotics, immunostimulants and probiotics, often as a combination of these (Fitt et al. 1992; Kesarcodi-Watson et al. 2008; Prado et al. 2010). Between these methods, probiotics is a consolidate technique already used in fish larval nutrition (Taoka et al. 2006; Fjellheim et al. 2010). Following the experience in fish larval rearing, probiotics have been successively utilized in marine bivalve larval rearing (KesarcodiWatson et al. 2010; Prado et al. 2010; Zhou et al. 2009). Riquelme et al. (1997) found first probiotic in bivalves, that was the bacterium Alteromonas holoplanktis in Agropecten purpuratus gonads, after that, several studies followed on marine bivalves species (Estes et al. 2004; Kesarcodi-Watson et al. 2009b). Probiotics have been successfully used in Pacific oyster (Crassostrea gigas) (Douillet and Langdon 1994; Gibson et al. 1998; Nicolas et al. 2004), in Chilean scallop (Agropecten purpuratus) (Riquelme et al. 1995; Avendano and Riquelme 1999; Riquelme et al. 2000, 2001), in scallop (Pecten maximus) larvae (Ruiz-Ponte 
Table 1 Comparison between bacteria found in freshwater mussels and probiotics used in fish rearing

\begin{tabular}{|c|c|}
\hline Bacteria found in freshwater mussel & Probiotics in fish \\
\hline Bacillus sp. (Chittick et al. 2001) & $\begin{array}{l}\text { B. subtilis-Indian carp, in diet (Kesarcodi-Watson et al. 2008); } \\
\text { Bacillus sp. B2 in scallop (Agropecten) (Prado et al. 2010); B. } \\
\text { subtilis; B. megaterium; B. polymyxa; B. licheniformis—shrimp, in } \\
\text { diet (Kesarcodi-Watson et al. 2008); Bacillus, commercial product } \\
\text { (Moryartry 1997); B. subtilis, commercial product (Queiroz and } \\
\text { Boyd 1998) }\end{array}$ \\
\hline Streptococcus (Chittick et al. 2001) & Streptococcus fecium in Tilapia (Kesarcodi-Watson et al. 2008) \\
\hline $\begin{array}{l}\text { Aeromonas hydrophila (Chittick et al. 2001; Starliper } \\
\text { et al. 2008) Aeromonas sp. (Starliper et al. 2008) }\end{array}$ & $\begin{array}{l}\text { A. hydrophila-Rainbow trout, in diet (Balcazar et al. 2006); A. } \\
\text { hydrophila-Rainbow trout, in diet (Kesarcodi-Watson et al. 2008). } \\
\text { A. hydrophila-Gold fish (Irianto and Austin 2002) }\end{array}$ \\
\hline $\begin{array}{l}\text { Vibrio fluviatilis (Chittick et al. 2001) Vibrio } \\
\text { alginolyctus (Chittick et al., 2001) }\end{array}$ & $\begin{array}{l}\text { Vibrio fluviatilis-Raibow trout; Vibrio sp. C33-Scallop } \\
\text { (Agropecten), oyster (Crassostrea) (Prado et al. 2010); Vibrio } \\
\text { alginolyctus-Atlantic salmon (Balcazar et al. 2006) }\end{array}$ \\
\hline Pseudomonas fluorescens (Starliper et al. 2008) & Pseudomonas sp. in scallop (Agropecten) (Prado et al. 2010) \\
\hline Flavobacterium columnare (Starliper et al. 2008) & $\begin{array}{l}\text { Flaviobacterimu sp. (Balcazar et al. 2006); Flaviobacterimu sp. co- } \\
\text { culture Chaetoceros and Isochrysis (Kesarcodi-Watson et al. 2010); } \\
\text { Flaviobacterimu sp. in scallop (pecten) (Prado et al. 2010) }\end{array}$ \\
\hline
\end{tabular}

et al. 1999) and in New Zealand green lipped mussel (Perna canaliculus) (Kesarcodi-Watson et al. 2009a). Also farmed gastropods, Haliotis midae fed a probiotic-supplemented diet showed improved survival and growth rate (Macey and Coyne 2005).

Considering that the gastrointestinal tract of mollusks hosts a large number of microorganisms closely influenced by those found in the natural environment, an ideal probiotic is a microorganism naturally occurring in the healthy bivalve that should be isolated and successively inoculated in the water with bivalve larvae (Prado et al. 2010). Unfortunately, until this moment the studies on freshwater microbial flora are scarce and they are primarily focused on the risks for human health (Starliper et al. 2008; Chittick et al. 2001; Langdon et al. 2006; Starliper 2008; Teplitski et al. 2009) and natural feeding (Johnson et al. 1993; Frischer et al. 2000). On the other side, considering the probiotics in marine bivalves, the list of those currently used is wide (Kesarcodi-Watson et al. 2010; Prado et al. 2010) considering also that symbiotic microbial flora interacts with cultured algae (Nicolas et al. 2004; Schulze et al. 2006; Avendano and Riquelme 1999; Salvesen et al. 2000). Kesarcodi-Watson et al. (2009a) developed an interesting bioassay, based on the use of tissue culture dishes, useful to select bacterial strains as probiotics in New Zealand green lipped mussel larval nutrition. Pilot tests carried out under hatchery conditions, confirmed the usefulness of this screening method that could be used in freshwater mussel. To suggest a list of potential probiotics candidates for freshwater mussel larvae, a comparison between the bacteria found in the intestinal tract of unionids with symbiotic bacteria or probiotics already found and used in fish larval nutrition has been proposed (Table 1). This table can be used as a reference point for future study on probiotics for freshwater mussels. Another approach to the study of probiotics is focused not on reared animals but on the farm environment, in particular the hatchery. This is particularly interesting because it can be used as complementary to previous ones. Skjermo and Valdestein (1999) successfully proposed this method based on the microbiological control of water in salmon farming and called it "matured water" method.

\section{The future perspectives}

Larval nutrition is the most important phase of the freshwater bivalve farming to be clarified in the next years for optimal development of this sector of aquaculture. Following the example of marine bivalves, probiotics and aquatic microbial control of water in the hatcheries will play a key role also in freshwater bivalves. In general terms, to promote freshwater bivalve farming, the diversification of production and finalities is a crucial issue and the researchers need to explore new applications of bivalves rearing taking in consideration bivalve potentialities. Conservation aquaculture and pearl production are not sufficient to guarantee relevant 
research and future economic investments, other applications must be investigated as integrated productions, bioindication studies and protein source for fish feeds, and finally education projects. Moreover, utilization of non-native bivalves must be investigated, to transform (partially) this threat in an opportunity obtaining at the same time a method to control their expansion. Bivalves, particularly mussels, are highly efficient filter feeders; they can filter 30-60 times their volume of water per hour and not only deplete the plankton from the water column, but also accumulate nutrients. This filtration activity has negatively affected North America freshwater systems, in the case of zebra mussel (Roditi et al. 1996), but there is a positive aspect that represents a great opportunity in bioremediation projects. European unionids have been used for integrated projects of aquaculture (MacDonald and Robinson 2011); Prins and Smaal (1994) showed that blue mussel (Mytilus edulis) strongly contributed to nitrogen remineralization in Oosterschelde estuary, Neterland; a biofiltration system based on Corbicula fluminea has been proposed as water treatment to remove phosphoruscontaining material from agricultural wastewater streams (Riley 2008). Chilean freshwater mussels (Diplodon chilensis) have been successfully used as a biocontrol system in salmon farming eutrophication (Soto and Mena 1999).

Another application for the use of freshwater mussels is the utilization of freshwater mussel meal in fish nutrition. Blue mussels are usually used in lobster (Homarus spp.) nutrition as feed attractants and in the fish broodstock nutrition (Myers and Tlusty 2009). Following the example of blue mussel utilization in rainbow trout (Oncorhynchus mykiss) artificial diets (Berge and Austreng 1989), freshwater mussel meal has been used as attractant in ornamental fish nutrition and in artificial feed for rainbow trout (Sicuro et al. 2010), but considering the low price of fish meal, that is the main ingredient for fish feed in aquaculture, the best perspectives for freshwater meal use in fish nutrition are in ornamental fish, broodstock and fish larval nutrition. This fact represents an opportunity economically suitable for freshwater mussel meal utilization and also non-native species can be also investigated for these applications. Looking at recent evolution of aquaculture, it is possible to see several cases where non-native species have become development opportunity, as Manila clam in Italy and Pacific oyster in France. Similarly, the utilization of non-native freshwater bivalves could reduce their future expansion. Finally freshwater mussels, for their rusticity and for their peculiar biological cycle that includes a parasitic larval stage, are ideal tools for education projects on freshwater ecosystems in primary and secondary schools.

Acknowledgments This paper has been written during a sabbatical semester that I spent in 2011 in the Aquatic, Epidemiology and Conservation Laboratory, Department of Population Health and Pathobiology, College of Veterinary Medicine, North Carolina State University. I am grateful to prof. Jay Levine for mentoring me. I also thank Chris Eads and Tom Fox for their support during my research.

Open Access This article is distributed under the terms of the Creative Commons Attribution License which permits any use, distribution, and reproduction in any medium, provided the original author(s) and the source are credited.

\section{References}

Avendano RE, Riquelme CE (1999) Establishment of a mixed culture probiotics and microalgae as food for bivalve larvae. Aquac Res 30:893-900

Balcazar JL, Ignacio de Blas I, Zarzuela I, Cunningham D, Vendrell D, Muzquiz JL (2006) The role of probiotics in aquaculture. Vet Microbiol 114:173-186

Berge GM, Austreng E (1989) Blue mussel in feed for rainbow trout. Aquaculture 81:79-90

Blankenship HL, Daniels E (2004) A Scientific anc Systematic Redesign of Washingtihn State Salmonid Hatcheries. In: Proceeding of American Fishery Society Symposium, 16-18 June 2003, pp 561-584, Boise, ID

Bogan AE (1993) Freshwater bivalve extinctions (Mollusca: Unionida): a search for causes. Am Zool 33:599-609

Bogan AE (2008) Global diversity of freshwater mussels (Mollusca, Bivalvia) in freshwater. Hydrobiologia 595:139-147

Bogan AE, Roe KJ (2008) Freshwater bivalve (Unioniformes) diversity, systematics, and evolution: status and future directions. J N Am Benthol Soc 27(2):349-369

Bronzi P, Rosenthal H, Arlati G, Williot P (1999) A brief overview on the status and prospects of sturgeon farming in Western and Central Europe. J Appl Ichthyol 15:224-227

Buddensienk V (1995) The culture of juvenile freshwater pearl mussels Margaritifera margaritifera L. in cages: a contribution to conservation programmes and the knowledge of habitat requirements. Biol Conserv 74:33-40

Cappelletti C, Cianfanelli S, Beltrami ME, Ciutti F (2009) Sinanodonta woodiana (Lea, 1834) (Bivalvia: Unionidae): a new nonindigenous species in Lake Garda (Italy). Aquat Invasions 4(4):685-688 
Chakraborty S, Ray M, Ray S (2008) Sodium Arsenite induced alteration of hemocyte density of Lamellidens marginalis-an Edible Mollusk from India. Clean 36(2):195-200

Chebanov M, Billard R (2001) The culture of sturgeons in Russia: production of juveniles for stocking and meat for human consumption. Aquat Living Resour 14:375-381

Chittick B, Stoskopf M, Law M, Overstreet R, Levine J (2001) Evaluation of potential health risks to Eastern Elliptio (Elliptio complanata) (Mollusca: Bivalvia: Unionida:Unionidae) and implications for sympatric endangered freshwater mussel species. J Aquat Ecosyst Stress Recovery 9:35-42

Diana JS (2009) Aquaculture production and biodiversity conservation. Bioscience 59:78-81

Douillet PA, Langdon CJ (1994) Use of a probiotic for the culture of larvae of the Pacific oyster (Crassostrea gigas Thunberg). Aquaculture 119:25-40

Englund D, Brunberg A, Jacks G (2008) A case study of a freshwater pearl mussel (Margaritifera margaritifera) population in central Sweden. Geogr Ann A 90(4):251-258

Estes RM, Friedman CS, Elston RA, Herwig RP (2004) Pathogenicity testing of shellfish hatchery bacterial isolates on Pacific oyster Crassostrea gigas larvae. Dis Aquat Organ 58:223-230

FAO (1986) Technical assistance on pearl culture in Bangladesh. TCP/BGD/4508. Field Document 1, Project report S2622, p52. Available from URL: http://www.fao.org/docrep/field/003/S2622E/S2622E00.htm. Accessed Oct 2013

Fitt W, Heslinga G, Watson T (1992) Use of antibiotics in the mariculture of giant clams (F. tridacnidae). Aquaculture 104:1-10

Fjellheim AJ, Klinkenberg G, Skjermo J, Aasen IM, Valdstein O (2010) Selection of candidate probionts by two different screening strategies from Atlantic cod (Gadus morhua L.) larvae. Vet Microbiol 144:153-159

Frischer ME, Nierzwicki-Bauer SA, Parsons RH, Vathanodorn K, Waitkus KR (2000) Interactions between zebra mussels (Dreissena polymorpha) and microbial communities. Can J Fish Aquat Sci 57(3):591-599

Gatenby MC, Neves RJ, Parker BC (1994) Development of a diet for rearing early juvenile freshwater pearly mussels. J Shellfish Res 13(1):289-299

Gibson LF, Woodworth J, George AM (1998) Probiotic activity of Aeromonas media on the Pacific oyster, Crassostrea gigas, when challenged with Vibrio tubiashii. Aquaculture 169:111-120

Hallermann EM (2004) Hatcheries as tools to support sustainable fisheries resources. American Fisheries Society Symposium, 12-16 December 2004, pp 213-230, Bethesda, MD

Hastie LC (2006) Determination of mortality in exploited freshwater pearl mussel (Margaritifera margaritifera) populations. Fish Res 80(2):305-311

Henley WF, Zimmerman LL, Neves RJ, Kidd MR (2001) Design and Evaluation of Recirculating Water Systems for Maintenance and Propagation of Freshwater Mussels. N Am J Aquac 63:144-155

Hua D, Neves RJ (2007) Captive survival and pearl culture potential of the pink Heelsplitter Potamilus alatus. N Am J Aquac 69:147-158

Irianto A, Austin B (2002) Probiotics in aquaculture. J Fish Dis 25:633-642

Johnson J, Cotner J, Gardner W (1993) Zebra mussel grazing of bacteria in Saginaw Bay. In: Conference of the International Association for Great Lakes Research, p 95, De Pere, WI

Jones JW, Mair RA, Neves RJ (2005) Factors affecting survival and growth of juvenile freshwater mussels cultured in recirculating aquaculture systems. N Am J Aquacult 67:210-220

Jungwirthi M, Kossmann H, Schmutz S (1989) Rearing of Danube Salmon (Hucho hucho L.) fry at different temperatures, with particular emphasis on freeze-dried zooplankton as dry feed additive. Aquaculture 77:363-371

Karatayev AY, Padilla DK, Minchin D, Boltovskoy D, Burlakova LE (2007) Changes in global economies and trade: the potential spread of exotic freshwater bivalves. Biol Invasions 9:161-180

Kesarcodi-Watson A, Kaspar H, Lategan MJ, Gibson L (2008) Probiotics in aquaculture: the need, principles and mechanisms of action and screening processes. Aquaculture 274:1-14

Kesarcodi-Watson A, Kaspar H, Lategan MJ, Gibson L (2009a) Screening for probiotics of Greenshell ${ }^{\mathrm{TM}}$ mussel larvae, Perna canaliculus, using a larval challenge bioassay. Aquaculture 296:159-164

Kesarcodi-Watson A, Kaspar H, Lategan MJ, Gibson L (2009b) Two pathogens of GreenshellTM mussel larvae, Perna canaliculus: vibrio splendidus and a V. coralliilyticus/neptunius-like isolate. J Fish Dis 32:499-507

Kesarcodi-Watson A, Kaspar H, Lategan MJ, Gibson L (2010) Alteromonas macleodii 0444 and Neptunomonas sp. 0536, two novel probiotics for hatchery-reared Greenshell ${ }^{\mathrm{TM}}$ mussel larvae, Perna canaliculus. Aquaculture 309:49-55

Lahnsteiner F, Kletzl M, Weismann T (2009) The risk of parasite transfer to juvenile fishes by live copepod food with the example Triaenophorus crassus and Triaenophorus nodulosus. Aquaculture 295:120-125

Langdon C, Close D, Bradley P (2006) The potential role of freshwater mussels in reducing Giardia and other human pathogens in watersheds of the Pacific northwest. J Shellfish Res 25(2):746-755

Lydeard C, Cowie RH, Ponder WF, Bogan AE, Bouchet P, Clark SA, Cummings KS, Frest TJ, Gargominy O, Herbert DG, Hershler R, Perez KE, Roth B, Seddom M, Strong EE, Thompson FG (2004) The Global decline of nonmarine mollusks. Bioscience 54(4):321-328

MacDonald BA, Robinson SMC (2011) Barrington. Feeding activity of mussels (Mytilus edulis) held in the field at an integrated multi-trophic aquaculture (IMTA) site (Salmo salar) and exposed to fish food in the laboratory. Aquaculture 314:244-251

Macey BM, Coyne VE (2005) Improved growth rate and disease resistance in farmed Haliotis midae through probiotic treatment. Aquaculture 245:249-261

Marshall R, McKinley S, Pearce CM (2010) Effects of nutrition on larval growth and survival in bivalves. Rev Aquac 2(1):33-55

Maynard DJ, Flagg TA, Iwamoto RN, Wahanken CVM (2004) A review of recent studies investigating seminatural rearing strategies as a tool for increasing pacific salmon postrelease survival. American Fishery Society Symposium, 16-18 June 2003, Boise, ID

Moryartry DJV (1997) The role of microorganisms in aquaculture ponds. Aquaculture 151:333-349 
Myers A, Tlusty MF (2009) A long-term assessment of the physiological effects of herring (Clupea harengus) as a dietary component of the American lobster (Homarus americanus). New Zeal J Mar Fresh 43(1):173-183

Neves RJ (1999a) Biological feasibility of freshwater mussel and pearl culture in Gulf Coast states. Gulf Mex Sci 17(2):103-108

Neves RJ (1999b) Conservation and commerce: management of freshwater mussel (Bivalvia: Unionoidea) resources in the United States. Malacologia 41(2):461-474

Neves RJ (2004) Propagation of endangered freshwater mussels in North America. J Conchol Spec Pub 3:69-80

Nichols S, Garling D (2002) Evaluation of substitute diets for live algae in the captive maintenance of adult and subadult Unionidae. J Shellfish Res 21(2):875-881

Nichols SJ, Wilcox DA (1997) Burrowing saves Lake Erie clams. Nature 389:921

Nicolas JL, Corre S, Cochard JC (2004) Bacterial population association with phytoplankton cultured in a bivalve hatchery. Microb Ecol 48:400-413

Olson DE, Spateholts B, Paya N, Campton D (2004) Salmon Hatcheries for the 21st Century: a Model at Warm Springs National Fish Hatchery. In: Proceeding of American Fishery Society Symposium, Boise, Idaho, 16-18 June 2003. 44: 585-602

Paragamian VL, Beamesderfer RCP (2004) Dilemma on the Kootenai River: the risk of extinction or when does the hatchery become the best option? In: American Fisheries Society Symposium, p. 2199, Bethesda, MD

Parker BC, Patterson MA, Neves RJ (1998) Feeding interactions between native freshwater mussels (Bivalvia: Unionidae) and zebra mussels (Dreissena polymorpha) in the Ohio River. Am Malacol Bull 14(2):173-179

Prado S, Romalde JL, Barja JL (2010) Review of probiotics for use in bivalve hatcheries. Vet Microbiol 145(3):187-197

Prins TC, Smaal AC (1994) The role of the blue mussel Mytilus edulis in the cycling of nutrients in the Oosterschelde estuary (The Netherlands). Hydrobiologia 282(1):413-429

Queiroz J, Boyd C (1998) Effects of a bacterial inoculum in channel catfish ponds. J World Aquacult Soc 29:67-73

Raikow DF, Hamilton SK (2001) Bivalve diets in a midwestern US stream: a stable isotope enrichment study. Limnol Oceanogr 46(3):514-522

Reis J (2003) The freshwater pearl mussel [Margaritifera margaritifera (L.)] (Bivalvia, Unionoida) rediscovered in Portugal and threats to its survival. Biol Conserv 114(3):447-452

Riley LW (2008) Freshwater clams as a treatment mechanism for phosphorus in agricultural wastewater. Dissertations and Theses, University of Florida

Riquelme C, Hayashida G, Vergara N, Vasquez A, Morales Y, Chavez P (1995) Bacteriology of the scallop Argopecten purpuratus (Lamarck, 1819) cultured in Chile. Aquaculture 138:49-60

Riquelme C, Araya R, Vergara N, Rojas A, Guaita A, Candia M (1997) Potential probiotic strains in the culture of the Chilean scallop Argopecten purpuratus (Lamarck, 1819). Aquaculture 154:17-26

Riquelme C, Araya R, Escribano R (2000) Selective incorporation of bacteria by Argopecten purpuratus larvae: implications for the use of probiotics in culturing systems of the Chilean scallop. Aquaculture 181:25-36

Riquelme CE, Jorquera MA, Rojas AI, Avendano RE, Reyes N (2001) Addition of inhibitor-producing bacteria to mass cultures of Argopecten purpuratus larvae (Lamarck, 1819). Aquaculture 192:111-119

Roditi HA, Caracon NF, Cole JJ, Strayer DL (1996) Filtration of Hudson River Water by the Zebra Mussel (Dreissena polymorpha). Estuaries 19(4):824-832

Ruiz-Ponte JF, Samain JL, Sánchez J, Nicolas JL (1999) The benefit of a Roseobacter species on the survival of scallop larvae. Mar Biotechnol 1:52-59

Salvesen I, Reitan KI, Skjermo J, Øie G (2000) Microbial environments in marine larviculture: impacts of algal growth rates on the bacterial load in six microalgae. Aquacult Int 8:275-287

Schulze AD, Alabi AO, Tattersall-Sheldrake AR, Miller KM (2006) Bacterial diversity in a marine hatchery: balance between pathogenic and potentially probiotic bacterial strains. Aquaculture 256:50-73

Secor DH, Arefjev V, Nikolaev A, Sharov A (2000) Restoration of sturgeons: lessons from the Caspian Sea Sturgeon Ranching Programme. Fish Fish 1:215-230

Sicuro B, Prearo M, Forneris G (2006) The effect of disinfection with ozone in restocking brown trout farm in north Italy. Ittiopatologia 3:43-56

Sicuro B, Mioletti S, Abete C, Amedeo S, Panini E, Forneris G (2010) Potential utilisation of farmed freshwater mussels (Anodonta anatina and Unio mancus) in Italy. Cuban J Agr Sci 44(4):409-416

Skjermo J, Vadstein O (1999) Techniques for microbial control in the intensive rearing of marine larvae. Aquaculture 177:333-343

Soto D, Mena G (1999) Filter feeding by the freshwater mussel, Diplodon chilensis, as a biocontrol of salmon farming eutrophication. Aquaculture 171:65-81

Starliper CE (2008) Recovery of a fish pathogenic bacterium, Aeromonas salmonicida, from ebonyshell mussels Fusconaia ebena using nondestructive sample collection procedures. J Shellfish Res 27(4):775-782

Starliper CE, Neves RJ, Hanlon S, Whittington P (2008) A survey of the indigeous microbiota (bacteria) in three species of mussels from the Clinch and Holston rivers, Virginia. J Shellfish Res 27(5):1311-1317

Stefansson SO, McGinnity P, Thrandur Bjornsson B, Schreck CB, McCormicke MD (2003) The importance of smolt development to salmon conservation, culture, and management: perspectives from the 6th International Workshop on Salmonid Smoltification. Aquaculture 222:1-14

Steffens W, Jähnichen H, Frank F (1990) Possibilities of sturgeon culture in Central Europe. Aquaculture 89:101-122

Taoka Y, Maeda H, Jo JY, Kim SM, Park SI, Yoshikawa T, Sakata T (2006) Use of live and dead probiotic cells in tilapia Oreochromis niloticus. Fish Sci 72:755-766

Teplitski M, Wright AC, Lorca G (2009) Biological approaches for controlling shellfish-associated pathogens. Curr Opin Biotech 20:185-190 
Wacker A, Becher P, von Elert E (2002) Food quality effects of unsaturated fatty acids on larvae of the zebra mussel Dreissena polymorpha. Limnol Oceanogr 47(4):1242-1248

Williams JD, Warren ML Jr, Cummings KS, Harris JL, Neves RJ (1993) Conservation status of freshwater mussels of the United States and Canada. Fisheries 18(9):6-22

Xu Q, Guo L, Xie J, Zhao C (2011) Relationship between quality of pearl cultured in the triangle mussel Hyriopsis cumingii of different ages and its immune mechanism. Aquaculture 315:196-200

Young M, Williams J (1983) The status and conservation of the freshwater pearl mussel Margaritifera margaritifera Linn. Great Britain. Biol Conserv 25(1):35-52

Zhou QL, Li K, Jun X, Bo L (2009) Role and functions of beneficial microorganisms in sustainable aquaculture. Bioresour Technol 100:3780-3786 